RESEARCH PAPER

\title{
New frontier, new power: the retail environment in Australia's dark market
}

\section{S M Carter}

\begin{abstract}
Objective: To investigate the role of the retail environment in cigarette marketing in Australia, one of the "darkest" markets in the world.

Design: Analysis of 172 tobacco industry documents; and articles and advertisements found by hand searching Australia's three leading retail trade journals.

Results: As Australian cigarette marketing was increasingly restricted, the retail environment became the primary communication vehicle for building cigarette brands. When retail marketing was restricted, the industry conceded only incrementally and under duress, and at times continues to break the law. The tobacco industry targets retailers via trade promotional expenditure, financial and practical assistance with point of sale marketing, alliance building, brand advertising, and distribution. Cigarette brand advertising in retail magazines are designed to build brand identities. Philip Morris and British American Tobacco are now competing to control distribution of all products to retailers, placing themselves at the heart of retail business. Conclusions: Cigarette companies prize retail marketing in Australia's dark market. Stringent point of sale marketing restrictions should be included in any comprehensive tobacco control measures. Relationships between retailers and the industry will be more difficult to regulate. Retail press advertising and trade promotional expenditure could be banned. In-store marketing assistance, retail-tobacco industry alliance building, and new electronic retail distribution systems may be less amenable to regulation. Alliances between the health and retail sectors and financial support for a move away from retail dependence on tobacco may be necessary to effect cultural change.
\end{abstract}

Correspondence to: Stacy M Carter, School of Public Health, Room 128A Building A27, University of Sydney NSW' 2006, Australia; carters@health.usyd.

A ustralia is a highly restricted marketing environment for tobacco. Federal Australian law has made most forms of tobacco marketing illegal, starting in 1976 and reaching a watershed in the (Federal) Tobacco Advertising Prohibition (TAP) Act 1992. ${ }^{1}$ On a background of existing television, radio, and cinema bans, the TAP Act prohibited print advertising, domestic sponsorships, and billboard advertising with some exceptions, including "internationally significant" sponsorships and advertising in retail trade publications. ${ }^{1}$ The TAP Act permits in-store advertising, although this is overridden if stronger State legislation exists. Australia's eight states and territories are inconsistent on point of sale (POS) advertising and promotions. ${ }^{2}$

This paper was stimulated by a desire to understand how manufacturers approach the role of retailers in a restricted market like Australia. Another paper in this supplement explains the difference between above-the-line marketing (mass media advertising) and below-the-line marketing (which includes POS marketing). It also describes the general trend across industries towards integrated marketing, the tobacco industry's increased investment in below-the-line advertising to prepare consumers for impending restrictions on above-the-line, and the non-retail marketing strategies used to promote cigarettes in Australia. ${ }^{3}$ Another relevant paper in this supplement discusses the three brand categories operating in Australia-premium, mainstream, and supervalue. $^{4}$

Some international research has considered the role of the retailer in marketing. US research has shown that retailer incentive payments (for POS agreements) are growing ${ }^{5}$; retailers receive proportionally more incentives from tobacco than other industries ${ }^{6}$; and $81 \%$ of industry marketing expenditure is on these "promotional allowances", through contracts which stipulate terms such as in-store placement and reimburse retailers for selling at cheaper prices. ${ }^{7}$ The US industry's retail marketing plans reflect the age, race, and wealth of the retailer's customers, ${ }^{8-10}$ and POS promotions are used more extensively in contexts where other industry strategies are curbed by regulation. ${ }^{11}$ Retail marketing and relationship building with retailers in the UK has also been described. ${ }^{12}$ One small study of retailer compliance with new marketing restrictions in Western Sydney showed a high degree of compliance, and suggested that non-compliant retailers had sometimes been misinformed by industry representatives. ${ }^{13}$ Other than this study, there has been little exploration of the significance of retail marketing in Australia in the literature.

\section{METHODS}

This paper draws on three sources: tobacco industry documents, reporting in Australian retail trade publications, and cigarette advertising in Australian retail trade publications.

Tobacco industry documents came from sites on the world wide web arising from litigation in the USA. ${ }^{14}$ Documents came from the primary sites of the manufacturers, ${ }^{15}$ the Council for Tobacco Research, ${ }^{16}$ and the US Tobacco Institute, ${ }^{17}$ and the secondary sites of Tobacco Documents Online (Bliley, BC, Health Canada and Guildford Miscellaneous collections), ${ }^{18}$ the Canadian Council for Tobacco Control site, ${ }^{19}$ the British Columbia Ministry of Health Services site, $^{20}$ and the Center for Disease Control Guildford site. ${ }^{21}$ The search string (pagewood or moorabbin

Abbreviations: BATA, British American Tobacco Australia; PML, Philip Morris Australia Limited; POS, point of sale; TAP Act, Tobacco Advertising Prohibition Act; TPE, trade promotional expenditure 
or granville or australia or sydney or melbourne or brisbane or hobart or adelaide or perth or canberra or amatil or wills) has been used throughout the project to gather documents relating to the Australian market. Six hundred and ninety two of these were relevant to cigarette branding in Australia, and of these 172 dealt specifically with issues of transportability of brands and the importance of retailers. This paper presents only a subset of the evidence: all 172 documents are available from http://tobacco.health.usyd.edu.au/site/gateway/docs/search.htm. An overview of our approach to document searching and analysis is available elsewhere. ${ }^{22}$

The three main trade journals-Australian Retail Tobacconist, Retail World, and Australian Service Station and Convenience Store News (pre November 2001)/Australian Convenience Store News (post November 2001)—were searched by hand from 1990 to the present. All articles and corporate advertisements that mentioned tobacco products or companies were copied. Industry documents and articles from retail trade publications were collected and analysed in the same way. A materialist, intersubjective position was assumed ${ }^{23} 24$; the aim was to understand cigarette retailing from the industry and the retailers' point of view. All identified statements to cigarette retailers or about cigarette retailing were annotated verbatim, organised chronologically, and then grouped iteratively into emergent themes.

In addition advertisements for ready made cigarettes in retail trade publications were examined. All advertisements placed by Philip Morris Australia Limited (PML), British American Tobacco Australia (BATA), or Imperial Tobacco Limited for ready made cigarettes from January 2001 to June 2003 were colour copied. One hundred instances of advertising, comprising 44 unique advertisements for only 13 brands were identified from the 30 month period of study. Advertisements were classified into the three brand categories defined by the Australian cigarette industry: premium (quality, mostly international brand cigarettes), mainstream (the "Aussie" brands Peter Jackson and Winfield), and supervalue (budget cigarettes). ${ }^{4}$

The author further classified each unique advertisement according to five questions, which are defined in table 1 .

A positioning statement is defined as "the part of the brand identity and value proposition that is to be actively communicated to the target audience... [to] demonstrate an advantage over competitor brands"..25 26 Brand identity is defined as "a set of associations the brand strategist seeks to create or maintain... what the organisation wants the brand to stand for" and the "value proposition" is a statement of the benefits that the brand offers. ${ }^{25}{ }^{26}$ Examples of Australian positioning statements are "Anyhow, have a Winfield", "Longbeach 40s: more to enjoy", "Fresh is Alpine",

Table 1 Criteria for analysis of tobacco advertisements from retail trade publications

\begin{tabular}{|c|c|}
\hline Question & Yes if: \\
\hline $\begin{array}{l}\text { Was something "new" formally } \\
\text { announced in the advertisement? } \\
\text { Did a cigarette pack appear? }\end{array}$ & $\begin{array}{l}\text { The adjective "new" was used to } \\
\text { describe a featured brand or variant } \\
\text { A picture of one or more cigarette } \\
\text { packs appeared }\end{array}$ \\
\hline $\begin{array}{l}\text { Was imagery (excepting a } \\
\text { cigarette pack or trademark) } \\
\text { used? } \\
\text { Was retailing information } \\
\text { provided? }\end{array}$ & $\begin{array}{l}\text { Non-text photographs or graphics } \\
\text { appeared portraying something other } \\
\text { than a cigarette pack or trademark } \\
\text { The advertisement contained text } \\
\text { which actively addressed the retailer, } \\
\text { describing business benefits such as } \\
\text { profit margins, sales figures or brand } \\
\text { share }\end{array}$ \\
\hline $\begin{array}{l}\text { Was a positioning statement } \\
\text { used? }\end{array}$ & $\begin{array}{l}\text { The advertisement contained a } \\
\text { positioning statement for the brand }\end{array}$ \\
\hline
\end{tabular}

"Medium: when you want a flavourful mid tar cigarette", and "West Ice cool taste".

\section{RESULTS}

\section{The POS in Australian cigarette marketing}

The Australian industry has always used the retail environment as a conduit for personal communication with consumers. As early as 1955 Philip Morris promised retailers "free, top quality display material". ${ }^{27}$ By the 1960s Australia was "a lively active market with a great deal of aggressive advertising and point of sale", and Philip Morris employed 44 "salesmen". These salesmen serviced retailers and performed consumer tradeups. In a "tradeup" the salesman exchanged a packet of Philip Morris cigarettes for the cigarettes a consumer was smoking, an activity they were expected to perform opportunistically everywhere they went. ${ }^{28}$

In the 1970s and 1980s manufacturers provided retailers with everything from signs announcing opening hours, push/ pull door signs, menu boards and clocks, as well as in-store premiums (gifts with purchase, often linked to branded sports sponsorship), hostesses, competitions, and "switch selling" programmes. "Switch selling" occurred when a customer asked for a competitor brand of cigarettes in a shop: the company sales representative would offer to buy the customer a packet of their company's brand instead. ${ }^{29-32}$

\section{The rise of retail as marketing was restricted}

In 1992, a PML presentation argued: "new government restrictions are rapidly increasing the importance of retail marketing as a part of the overall marketing mix. With this comes aggressive competition for in-store space and importantly, cut through* to the consumer...".33 Previous to the TAP Act, above-the-line had been the primary vehicle for building brand image, and below-the-line strategies "provid[ed] important support for these established images".33 The "net result" of the TAP Act, argued PML's spokesperson, was that "we must now extend below the line programs to encompass the image building role... retail marketing is therefore no longer the support mechanism, [but] the primary communication vehicle". ${ }^{33}$

In the early 1990s, before and after the TAP Act was introduced, the industry poured resources into "big specials which both reward and involve smokers", ${ }^{34}$ including gondola end spectaculars (large three dimensional displays covering the entire end of a grocery aisle), competitions and sweepstakes, window displays, promotions in unique retail settings such as cafes and video stores, premiums, and more frequent changes in imagery, all in search of the holy grail of consumer attention and awareness. ${ }^{34-36}$ To create "overpowering" beach imagery in shops in the early days of PML's Longbeach brand, for example, old two dimensional display units were replaced by "full 3D representations of the beach environment", including "beach chairs... sand, seagulls and even footprints on the floor", supported by beach photographs incorporated into the pack, and themed premiums such as beach bags. ${ }^{33}$

On the eve of local sponsorship bans, PML wrote: "as of 1996, the primary point of communication between ourselves and our consumers will be inside a retail outlet... In-store POS material, discounted stock units, on-pack premium offers, strategically located stock displays in-store (as well as in windows and showcases), need to be dominated by PML... In summary, the spend focus has shifted from media, outdoor and consumer promotions to in-store [POS management], contracting for display space, partnerships with

* "Cut through" is marketing jargon for getting the consumer's attention above the "noise" of a crowded advertising environment. 
retailers to build business, and international sponsorships." ${ }^{\prime 36}$ Accordingly, by 1995 PML already had "long term agreements with retailers to ensure a dominant POS presence" in preparation for restrictions. ${ }^{36}$

\section{Responses to retail marketing restrictions}

Given the increased importance of retail in a restricted marketing environment, it is not surprising that, as various states limited POS promotions, the industry's retail strategies constricted only incrementally and under duress. Mass displays of cartons were used to "paint a billboard", but were soon noticed by regulators. ${ }^{37}$ When regulation prevented POS displays from including brand logos, brand colours were used instead through balloons and streamers. ${ }^{37}$ The same occurred for premiums. Originally items selected for their resonance with a brand's identity were branded with trademarks and offered as gifts with purchase. When trademarks on gifts were banned, the same gifts continued to be offered, in the colours of the brand, minus the trademark. In 1995, for example, smokers who bought two packs of Marlboro were offered a red cap with an Fl car (rather than a Marlboro logo) embroidered on it. ${ }^{36}$ When premiums for cigarette purchases were banned Wills gave retailers cricket bats to raffle to consumers who bought "anything to the value of a carton of Benson \& Hedges". ${ }^{36}$

Where possible, POS displays capitalised on the longstanding international sports sponsorships of the cigarette brands. This was seen by the manufacturers to provide "unquestionable legitimacy" at the POS: the familiarity of the link between the sport and the product and the synergy between the display and the sport, making consumers more comfortable with the marketing. ${ }^{38}$ Manufacturers remain willing to test the law-for example, with a recently used custom made silver bar-refrigerator holding Alpine cigarettes for sale in shops, illegal in $\mathrm{NSW}^{39}$ but tested by the manufacturers anyway. $\dagger$ PML believes that legislation forcing all cigarette products below the counter is probable across Australia in the medium term. ${ }^{40}$

\section{The new power of retailers and the industry's response}

Retailers are important to tobacco companies, as almost all cigarettes are sold in retail shops. Conversely, tobacco products are an extremely important category for many retail businesses. Unfortunately the retail sector is complex and availability and quality of data from public sources on retail cigarette sales is inconsistent, and thus difficult to summarise. The most comprehensive review available suggested that the margin of sales from cigarettes and tobacco as a proportion of gross margin was $71 \%$ for tobacconists, $20 \%$ for petrol stations, $17 \%$ for convenience, $11 \%$ for grocery, and $8 \%$ for mixed businesses. ${ }^{41}$ AC Nielsen creates an annual "Top 100 Brands" report on the grocery/supermarket sector based on sales value, and tobacco brands reliably inhabit six out of the top 10 places in this list, beaten only by Coca Cola. A report on the convenience store sector based on data from 2000 showed that the "cigarette" category accounted for $34.68 \%$ of total sales, far exceeding the next largest categories, beverages $(12.7 \%)$, milk $(8.03 \%)$, and confectionery $(7.86 \%){ }^{42}$ Although the data are difficult to pin down, there is no doubt that tobacco is important to the Australian retail sector.

Despite this apparent dependence on tobacco, a combination of the disappearance of above-the-line and concentration of the grocery market in Australia ${ }^{35}$ has put large retailers in

†A picture of this display unit can be viewed at http://www.ashaust. org.au/lv4/Lv4resources_tobacco_ads.htm particular in a strong negotiating position, and their loyalty is not guaranteed. Cigarette manufacturers maintain their relationships with retailers through five channels:

- trade promotional expenditure

- in-store display hardware and assistance with POS marketing

- corporate advertising and alliance building

- brand advertising direct to retailers

- a new, innovative electronic distribution system.

\section{Trade promotional expenditure}

Trade promotional expenditure (TPE) consists of retailer rewards, retailer loyalty programmes, rebates, and price supports. ${ }^{43-46}$ Price support and rebates direct to the retailer have been important since at least the 1960s and are increasingly $\mathrm{SO}^{46-49}$; in the absence of above-the-line advertising, the industry sees such pricing strategies as an increasingly important component of marketing. ${ }^{4}$ Loyalty programmes, in contrast, provide personal rewards to the retailer. In 1995, for example, PML ran an incentives scheme where retailers who placed Longbeach products prominently received "Longbeach Dollars" that could be spent at special auction nights. ${ }^{36}$ Such rewards must be sufficient to stimulate loyalty, as demonstrated by a failed 1994 Rothmans programme in which the rewards were too low. ${ }^{36}$

Display units and assistance with POS marketing RJ Reynolds reported that "[Australian] retailers immediately realised they were sitting on a "gold mine" at retail when print and $\mathrm{OOH}$ [out of hours] went away", and that as a result "the cost of the real estate went through the roof for Australia", forcing manufacturers to pay millions of Australian dollars for entire massive sets of retail display hardware to ensure "an advantaged position (the only piece of $2000 \mathrm{~cm}$ advertising) $)^{\prime \prime} .{ }^{37}$ Presumably this high cost was not just for the physical manufacture and installation of the units, but also a large fee for the right to use the only small piece of advertising space still available. PML has also acknowledged the importance of providing "innovative and customised instore [display] hardware" ${ }^{\prime 4}$ and other merchandising supports, shouldering the financial burden placed on retailers as a result of regulatory changes to the display of cigarettes. As RJ Reynolds noted: "[providing customised hardware] could play a major role in the future on who is perceived as the must-have companies. Retailers will be looking for new and creative ways to sell and merchandise cigarettes." ${ }^{\prime 37}$

Personal relationships between company representatives and retailers certainly appear to be valued in tobacco culture, as evidenced by awards to staff who excel in developing these "invaluable" relationships, ${ }^{50}$ and RJ Reynold's concern that after TAP "field people [were] totally confused about what [was] important... morale was five times worse than their expectations...[and] massive cultural/past behaviour change issues...existed". ${ }^{37}$ "Field people" assist retailers with everything from planograms or POGs-diagrams that show how and where to display products in order to increase customer purchases-to local area marketing-designing a stock selection and display tailor made for the demographics of the area in which the business is situated. ${ }^{51}$

In 1998 a Wills marketing manager illustrated just how serious the industry is about the minutiae of legal cigarette displays in regulation sales units. "We've been pushing retailers to put their cigarettes on the back wall, and we've had some initiatives where we've block-stocked our products. Instead of using a gravity-fed overhead dispenser, we've used a cascade tray to build up a big brand image. That orients the 
Table 2 Content of brand advertising in retail trade publications*

\begin{tabular}{lcccc}
\hline & Premium & Mainstream & Value & Total \\
\hline Number of unique advertisements & 23 & 11 & 10 & 44 \\
Number of brand families represented & 8 & 2 & 3 & 13 \\
New things announced & 8 & 5 & 4 & 17 \\
Cigarette pack appears & 19 & 11 & 9 & 39 \\
Imagery other than pack or trademark used & 20 & 9 & 6 & 35 \\
Text schools in retailing & 6 & 9 & 8 & 23 \\
Positioning statement used & 15 & 6 & 7 & 28 \\
*Number of unique advertisements January 2001 to June 2003 containing the listed content. &
\end{tabular}

product towards the consumer rather than having it facing the floor so you see more of the packet. The company has also changed the packet colours on one of its major brandsHorizon-so that it's a uniform blue. The aim of the exercise is instant recognition: along with Benson and Hedges, that's given us full gold and blue blocks on display and that helps our brands stand out." 52 The maintenance of "POS dominance", the strengthening of brand symbols and colours for instant recognition (via pack design), and the extension of these colours and the brands' personalities into the POS are continuing, carefully negotiated strategies, ${ }^{44}$ which also offer benefits to the retailer through highly organised and professional support for their merchandising.

\section{Alliance building}

The manufacturers promote their corporate image direct to retailers, and work to recruit retailers as political allies. ${ }^{44} 5354$ Retail trade publications contain both editorials consistent with tobacco rhetoric and photographs of tobacco manufacturers' constant presence at retail trade fairs, seminars, and award nights.

All three manufacturers take out frequent corporate advertising in retail trade journals, promising the retailer better service and support and urging them to work with company representatives to "maximize your profits". ${ }^{51} 55$ Each promotes a slightly different corporate identity. BATA, the serious industry leader, warns about the penalties for selling "chop chop" (illegal loose tobacco), promises to provide important information on its corporate website, and occasionally promotes the benefits of its brands with dense pages of text and graphs. PML's corporate image is more approachable, promising good service and support, brands that young people like to smoke, and bigger profits. Imperial, the new entrant, promises high tech "younique" service unencumbered by age and tradition, pledging "at Imperial, we take a more individual approach to your business. We listen, we learn and we deliver". Tobacco is part of retail culture.

\section{Brand advertising in trade publications}

Another important channel of communication between the industry and retailers is brand advertising in retail trade publications. A total of 44 such advertisements were examined as previously described. The results are presented in table 2 .

The advertisements examined did not solely or even primarily perform an information function. Only a minority announced something new, such as changes in pack size, pack style, or tar banding.

Two kinds of imagery appeared in the advertisements: packs or trademarks, and other imagery. Retailers selling cigarette products need to be able to identify cigarette packs: this enables them to make orders and provide customers with the products they request. It is thus unsurprising that advertising in retail trade publications frequently contained pictures of packs. However, it is not necessary for a retailer to be able to associate, for example, Alpine with deserted beaches or Winfield with boxing matches. Despite this, particularly in premium and mainstream advertising, imagery in addition to the trademark or pack was also used to

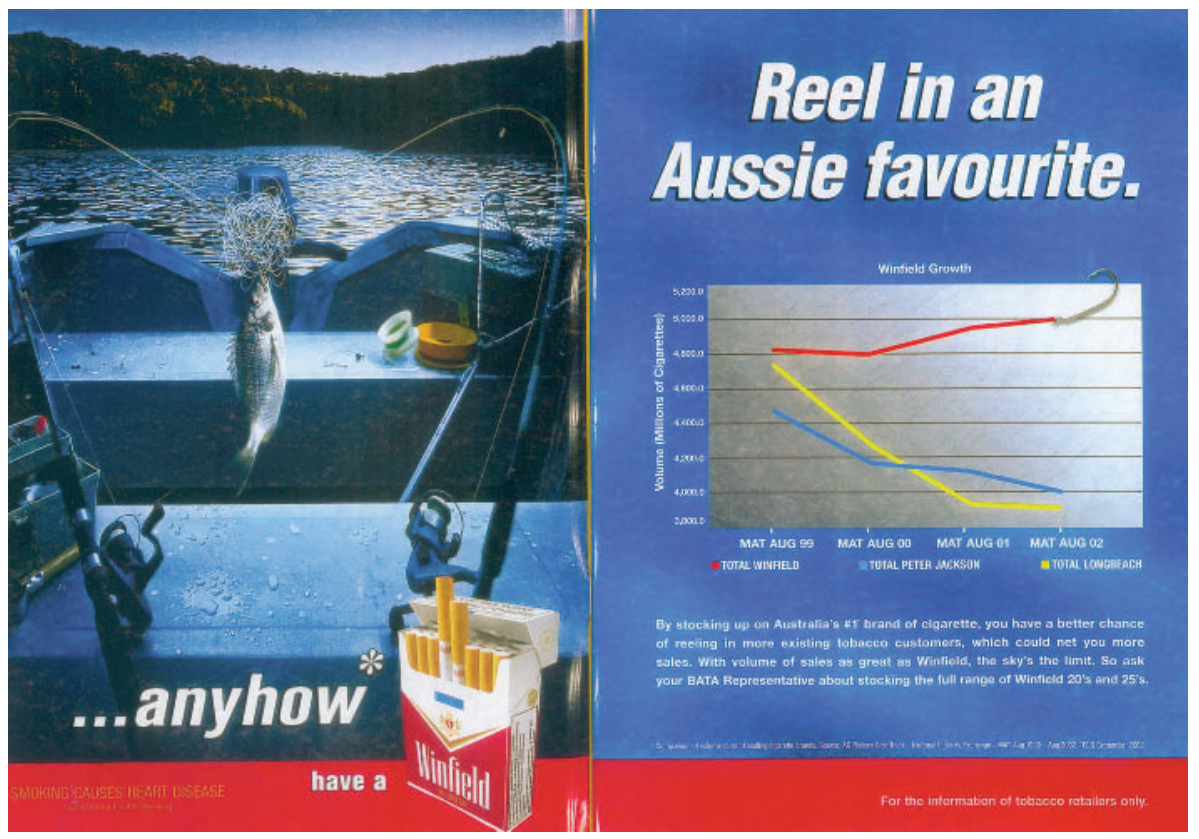

Figure 1 Mainstream advertisement, featuring positioning statement and imagery to build brand identity as well as retail information regarding sales volume. 
build these associations, attempting to create brand identities in the retailers' minds. ${ }^{25}{ }^{26}$ Imagery used included 1950s-style photographs; carefree beach scenes; abstract compositions based on electrical wires and computer chips; scenes of fishing, playing billiards or doing woodwork; nightclub-style lights; calm lakes; and tablecloths holding soothing cups of coffee.

The function of text in the advertisements also differed between the brand categories premium, mainstream, and supervalue. Positioning statements for high profit premium brands in particular were relatively abstract and focused on building brand identity, ${ }^{25} 26$ including "WHEN YOU'RE READY", "Fresh is Alpine", "LIVE\&WIRED", "CONNECT\&COMMIT", "The spirit of Marlboro in a light cigarette", "TEST IT", or "Passion for Power". Positioning statements for mainstream (fig 1) and supervalue brands more frequently emphasised the value proposition for the brand, such as "Australia's best value". Text which explicitly schooled in retailing was proportionally far less common for premium brands, consistent with the strong brand identity building orientation in their advertising.

\section{e-Distribution: placing tobacco companies at the heart of retail business}

A 1994 PML document observed: "the importance of the distribution system is growing as more marketing restrictions are placed on the industry." ${ }^{\prime 3}$ Accordingly, both BATA and PML have made globally unique efforts in the area of distribution in recent years. Both now have associated companies-e-Orders, established by PML in January 2001, and Quatro Four, launched by BATA in December 2001which operate as major integrated distribution hubs for small retailers (convenience, newsagents and petrol stations,) not just for tobacco products, but for a range of fast moving consumer goods including beverages, confectionery, ice cream, phone cards, convenience foods, dairy products, and automotive parts. ${ }^{56}$ e-Orders has 650 retail customers, and Quatro Four signed more than 2000 in its first nine months of operation, including both national chains and small independent retailers. ${ }^{56} 57$

Although at present retailers can use both systems simultaneously for different products, the trade thinks that "ultimately, there is only really room for one ordering system. The two electronic ordering specialists-e-Orders and Quatro-are scrambling for critical mass, for retailers and suppliers". ${ }^{56}$ e-Ordering has become a new frontier for competition and control between the manufacturers. The systems are currently advertised and editorialised about extensively in the trade literature, promising increased efficiency, tailoring, reduced supply chain costs to the retailer, integration with POS technology to enable automated stock management, and upcoming financial management services such as electronic invoicing and automatic account payment. Quatro Four offers incentives such as a years' free internet access for joining up, and promises convenience store owners that they will "help you compete with the big guys" (large grocery supermarket chains) by providing budget priced POS computer systems and other technology. ${ }^{56}$

It is important to note that these two initiatives are not centralised systems rolled out to Australia from overseasthey are local startup enterprises, and may in fact be implemented in overseas markets by PMI and BAT if they continue to be successful. Both systems contain tobacco advertising, position tobacco at the heart of a retailer's business along with other more benign product categories, and according to their spokespeople "will enable sales reps to go back to being professional representatives for their companies, helping retailers to build their sales, rather than spending inordinate amounts of time as order takers" ${ }^{58}$ It remains to be seen whether the manufacturers value sales representatives as they say they do, or whether an increase in e-ordering will lead to their redundancy.

\section{DISCUSSION}

The POS, always an important marketing environment for the Australian cigarette industry, has been transformed in the last five decades. Originally retail marketing was a mere support mechanism for above-the-line activities. When above-the-line was banned, the retail environment became the front line for brand building, absorbing massive resources and being seen as the primary site for sustaining relationships with the consumer. When retail was restricted by some states, the industry conceded only incrementally and under duress. The fact that the law is broken in retail marketing suggests that the retail promotions, however modest, are still highly prized in Australia's dark market.

Given that the industry explicitly defines retail as the new frontier in a dark market, effective tobacco control regulation should include stringent control of the retail environment. Given the industry's creativity and risk taking, the only way of preventing promotion of products at retail would be to require all products to be placed under the counter. Consumers could make purchases from product listings, and the law could define and standardise the format of these listings, allowing only product names and differentiating information such as pack size. The industry expects tobacco products to be forced under the counter, and their expectations should be fulfilled.

Another measure of the importance of the retail environment is the energy and resources expended by the industry on their relationships with retailers, demonstrated through trade promotional expenditure, in-store marketing assistance, alliance building, brand advertising in the trade press, and the new electronic retail distribution system. Regulating some of these aspects of the retail environment will be much more difficult than regulating the display of products.

Elements potentially more amenable to change are branded advertising in the retail press and TPE. Given that TPE impacts on price and thus can reduce the effectiveness of taxation strategies, the possibility of regulating it on economic as well as marketing grounds could be considered. Branded product advertising to retailers could potentially be banned in the upcoming review of the TAP Act. Brand identities are built in these advertisements by associating brands with distinctive imagery and by the use of brand positioning statements. In premium cigarette advertising in particular, brand identity building is more prominent than retailing information. It is hard to imagine why the tobacco industry would continue investing in such brand building activity if they did not think it was beneficial to the business of selling more cigarettes. Retailers' brand recognition requirements could be fulfilled by simple text lists and thumbnail package illustrations, a format already used for presenting information on brand share in some publications. Retailing information, such as market share and profit margins, could readily be provided without being associated with brand identity building imagery.

The tradition of the industry paying for in-store display hardware provides an opportunity. This precedent means that regulatory changes in retail displays could in future be defined as the industry's financial responsibility, reducing the burden on individual retailers. In contrast, the industry's traditional role in supporting and informing retailers as to the display of cigarettes should ideally be absorbed by health authorities, moving the emphasis from maximising sales to compliance with regulation. If the rise of e-distribution does 


\section{What this paper adds}

A small number of studies have investigated point of sale (POS) and relationships with retailers in international contexts, showing that the tobacco industry control the pricing and merchandising of their product by making substantial payments to retailers, that the industry match retail marketing to the stores' clientele, and that retail marketing increases when other forms of marketing are restricted.

Industry documents show that the POS, retailers and distribution became increasingly important as Australia's marketing environment became more restricted. Retailers' power increased, and as a result manufacturers now use their representatives, incentives, merchandising support, and retail publications to maintain retailer loyalty and build brand identities despite bans. Cigarette manufacturers now control distribution of tobacco and non-tobacco products to small retailers in Australia, placing themselves at the heart of retail business.

undermine the role of the sales representative it may provide a window of opportunity to effect this change.

The major threats to tobacco control in the retail sector appear to be the strong political alliances between tobacco and retail, profits that tobacco products offer to retailers, and the new developments in e-distribution. These will all be difficult to disrupt. It may be necessary for health groups to begin traditional alliance building activities with the retail sector, as has been done to an extent with the sporting sector in the advent of local sponsorship bans. It may also be necessary, as occurred in sport and the farming sector, to commit some proportion of public monies to support the movement of small businesses away from dependence on tobacco and into other categories. Given the tobacco tax windfall that the federal government collects and does not hypothecate, this seems a reasonable means by which to acknowledge the genuine financial dependence of some small businesses on tobacco.

If these regulatory challenges can be met, and other forms of below the line marketing are also regulated, Australia may, finally, become a truly dark market for tobacco.

\section{ACKNOWLEDGEMENTS}

Thanks to Simon Chapman and reviewers for helpful comments and Fiona Byrne for indispensable information management. The research reported in this paper was supported by grants from the National Health and Medical Research Council (2001-2003 \#153857) and the US National Institutes of Health (2001-2005 \# R01 CA87110-01Al).

\section{REFERENCES}

1 Commonwealth of Australia. Tobacco Advertising Prohibition Act. Commonwealth Consolidated Acts, 1992. http://www.austlii.edu.au/au/ legis/cth/consol_act/tapa1992314/index.html (Accessed 14 Jul 2003)

2 National tobacco legislation analysis: summary of existing legislation 2003. http://tobacco.health.usyd.edu.au/site/supersite/resources/pdfs/ aus_tobacco_legislation.pdf (Accessed 2 Sep 2003)

3 Carter SM. Going below the line: creating transportable brands for Australia's dark market. Tobacco Control 2003;12(suppl III):iii87-94.

4 Carter SM. The Australian cigarette brand as product, person, and symbol. Tobacco Control 2003;12(suppl III):iii79-86.

5 US Federal Trade Commission. Tobacco information page. US Federal Trade Commission, 2003. Accessed 14 Jul 2003. http://www.ftc.gov/bcp/menutobac.htm.

6 Feighery EC, Ribisl KM, Achabal DD, et al. Retail trade incentives: how tobacco industry practices compare with those of other industries. Am J Public Health 1999;89:1564-6.

7 Feighery E, Ribisl K, Clark PI, et al. How tobacco companies ensure prime placement of their advertising and products in stores: interviews with retailers about tobacco company incentive programmes. Tobacco Control 2003; 12:184-8.
8 Muggli ME, Pollay RW, Lew R, et al. Targeting of Asian Americans and Pacific Islanders by the tobacco industry: results from the Minnesota Tobacco Document Depository. Tobacco Control 2002;11:201-9.

9 Laws MB, Whitman J, Bowser DM, et al. Tobacco availability and point of sale marketing in demographically contrasting districts of Massachusetts. Tobacco Control 2002;11(suppl II):ii71-3.

10 Anon. Point-of-purchase tobacco environments and variation by store typeUnited States, 1999. MMWR Morb Mortal Wkly Rep 2002;51:184-7.

11 Slater S, Chaloupka FJ, Wakefield M. State variation in retail promotions and advertising for Marlboro cigarettes. Tobacco Control 2001;10:337-9.

12 Anderson S, Hastings G, MacFadyen L. Strategic marketing in the UK tobacco industry. Lancet Oncol 2002;3:481-6.

13 Goldthorpe I, Jorm L. Compliance with the Tobacco Advertising Prohibition Act 1991 in Western Sydney. Sydney: Western Sector Public Health Unit, 1994

14 Malone RE, Balbach ED. Tobacco industry documents: treasure trove or quagmire? Tobacco Control 2000:9:334-8.

15 Tobacco manufacturers' document websites. http://www.pmdocs.com-bin/ rsasearch.asp; http://www.bw.aalatg.com/public.asp; http:// www.lorillarddocs.com/cgi-bin/rsasearch.asp; http://www.rjirtocs.com/ rirtdocs/index.wmt?tab = home

16 Council for Tobacco Research document website. http://www.ctr-usa.org/ ctr/index.wmt?tab = home

17 Tobacco Institute document website. http://www.tobaccoinstitute.com/cgibin/Rsasearch.asp

18 Tobacco Documents Online. Smokescreen Corporation. http:// tobaccodocuments.org/

19 Canadian Council for Tobacco Control tobacco documents site. http:// www.ncth.ca/Guildford.nsf

20 British Columbia Ministry of Health Services tobacco documents site. http:// www.moh.hnet.bc.ca/cgi-bin/guildford_search.cgi

21 Center for Disease Control and Prevention Guildford tobacco documents site. http://www.cdc.gov/tobacco/industrydocs/index.htm

22 Chapman S, Bryne F, Carter SM. "Australia is one of the darkest markets in the world": the global importance of Australian tobacco control. Tobacco Control 2003;12(suppl III):iii 1-3.

23 Potter W. An analysis of thinking research about qualitative methods, 1 st ed. Mahwah New Jersey: Lawrence Erlbaum Associates Publishers, 1996.

24 Silverman D. Doing qualitative research: a practical handbook. 1st ed. London: SAGE publications, 2000

25 Aaker D, Joachimsthaler E. Brand leadership, 1st ed. London: Free Press Business/Simon \& Schuster, 2000.

26 Aaker D. Building strong brands, 1 st ed. New York: The Free Press/Simon \& Schuster, 1996

27 Retail Tobacco Traders Association. The Australian Tobacco annual, 1956 Dec 1955. Philip Morris. Bates No. 2504085100/5166. http:// legacy.library.ucsf.edu/tid/fnd71f00

28 Weissman G. Australia. 23 Mar 1964. Philip Morris. Bates No. 2012580062/0070. http://legacy.library.ucsf.edu/tid/wkb66e00

29 Smith P. WD \& HO Wills (Australia) Limited. [Memo to John J. Howley of Brown \& Williamson International Tobacco]. 29 Dec 1978. Brown \& Williamson. Bates No. 661076840/6844. http://legacy.library.ucsf.edu/ $\mathrm{rid} / \mathrm{bpe} 70 \mathrm{f00}$

30 Smith P. WD \& HO Wills (Australia) Limited. Kent merchandising. 29 Jun 1979. Brown \& Williamson. Bates No. 661076740/6742. http:// legacy.library.ucsf.edu/tid/ape70f00

31 License Agreement-Philip Morris, Australia. 20 Oct 1983. American Tobacco Company. Bates No. 968122490/2496. http:// legacy.library.ucsf.edu/tid/otgl la00

32 Batten K. PMA weekly highlights. 9 Mar 1984. Philip Morris. Bates No. 2023265803/5806. http://legacy.library.ucsf.edu/tid/bxr98e00

33 Philip Morris. [Presentation notes - slides 1-73 Australian retail market: notes for a NY Marketing Meeting]. 1992. Philip Morris. Bates No. 2504107172A/ 7192. http://legacy.library.ucsf.edu/tid/dii29e00

34 Philip Morris. 1991 original budget: Marketing Presentation. 3 Oct 1990. Oct 1990. Philip Morris. Bates No. 2504107139A/7171. http:// legacy.library.ucsf.edu/tid/aii29e00

35 Goldberg H. 1994 second revised forecast presentation, June 1994, New York. May 1994. Philip Morris. Bates No. 2504204001/4063. http:// legacy.library.ucsf.edu/tid/ygn32e00

36 Zufic D. [Forms part of a fax from Denis Zufic to Robert Sarmento on the topic of government restrictions that impede the Australian Tobacco Industry]. 16 Aug 1995. Philip Morris. Bates No. 2071284487/4490. http:// legacy.library.ucsf.edu/tid/nkq08d00

37 Stockdale B. Australia trip: topline learning (highly restricted market). 12 Feb 1997. RJ Reynolds. Bates No. 518093846/3852. http:// legacy.library.ucsf.edu/tid/ads90d00

38 Turner P. Consumer promotions. 21 May 1993. British American Tobacco. Bates No. 301742098/2099. hitp://tobaccodocuments.org/ health_canada/30174209.pdf (Accessed 24 Jun 2003)

39 New South Wales Parliament. Public health (tobacco) regulation 1999. New South Wales Consolidated Regulations 1999. http://www.austlii.edu.au/au/ legis/nsw/consol_reg/phr1999269/(Accessed 2 Sep 2003)

40 Philip Morris (Australia) Limited. Anti smoking agenda. 1998. Philip Morris. Bates No. 2072523055/3075. http://legacy.library.ucsf.edu/tid/lab06c00

41 PricewaterhouseCoopers Economic Studies and Strategies Unit. The significance of cigarettes and tobacco products to retailers. Canberra: Tobacco Institute of Australia, 1999.

42 C-Store Industry Report Part II. Retail World 2001;Aug 20-31: Report page 1 . 
43 Philip Morris International. Philip Morris Asia/Pacific three year plan, 1992 1994. Dec 1991. Philip Morris. Bates No. 2500064000/4226. http:// legacy.library.ucsf.edu/tid/wwi19e00

44 Philip Morris (Australia) Limited. 3 year plan, 1996-1998. 1996. Philip Morris. Bates No. 2047041415/1432. http://legacy.library.ucsf.edu/tid/ xzw06c00

45 Goldberg H. Australian highlights for the week ending 10 January 1996 and the month of December 1995. 11 Jan 1996. Philip Morris. Bates No. 2046386064B/6068. http://legacy.library.ucsf.edu/tid/lwu87d00

46 Philip Morris International-Australia. 1997. Philip Morris. Bates No. 2062389181. http://legacy.library.ucsf.edu/tid/iik93c00

47 Philip Morris (Australia) Limited. Philip Morris Limited minutes of Directors' Meeting held at the company's registered office, corner Chesterville and Cochranes Roads, Moorabbin, on Friday, 1st August 1969, at 12 Noon. 1 Aug 1969. Philip Morris. Bates No. 2015047961/7962. http:// legacy.library.ucsf.edu/tid/tnq34e00

48 Philip Morris (Australia) Limited. Superlights 30's. 18 Nov 1987. Philip Morris. Bates No. 2500113068/3074. http://legacy.library.ucsf.edu/tid/ill19e00

49 Goldberg H. Australian highlights for the week ending 22 January, 1997. 23 Jan 1997. Philip Morris. Bates No. 2074162304B/2305. http:// legacy.library.ucsf.edu/tid/pvd52c00
50 Philip Morris. Ring Award introductions at the PMI/KFI dinner Friday, October 18, 1996. Australia: 18 Oct 1996. Philip Morris. Bates No. 2073765218/5239. http://legacy.library. ucsf.edu/tid/ndw85c00

51 British American Tobacco Australasia. [Advertisement]. Retail World 2002;(15-26 April).

52 Swanton L. Tighter laws drive cigarette company creativity. Australian Service Station and Convenience Store News 1998;(May/Jun):38-39.

53 Gee L. Philip Morris retail focus. Jun 1998. Philip Morris. Bates No. 2063552738/2749. http://legacy.library.ucsf.edu/tid/sna42d00.

54 British American Tobacco Australasia. [Advertisement]. Retail World 2001 ; (Jul 23-Aug 3):14.

55 No author. Tobacco category review. Retail World 2001;54(Nov 26-Dec 7): 11-13.

56 Anon. e-Fast and e-Easy ordering. Australian Convenience Store News 2003;(Jan/Feb):18-19.

57 Anon. Shell trials Quatro Four. Australian Convenience Store News 2002;(Nov/Dec):36.

58 Anon. New entrant pledges to automate the industry. Australian Convenience Store News 2001 ;(Nov/Dec):34-35. 